\title{
Code Mixing as Communicative Function in Sold for Silver
}

\author{
Raudah Arsanti \\ Balikpapan University \\ arsantiraudah@gmail.com
}

\begin{abstract}
:
This research studies of code mixing as communicative function in the novel Sold for Silver by Janet Lim. There are two questions proposed, they are what are the types of code mixing used and how is communicative function expressed with code mixing in the novel. The theory used in this research is sociolinguistics theory with the analysis using Wardaugh theory of code mixing; the methodology employed is qualitative research in which the researcher tried to present the issues descriptively. The researcher collected the data from the novel as the primary data of this research. The result of this research is the researcher found the type of code mixing used and it is classified into two types; intra-sententially and inter-sententially. Meanwhile, the researcher also found metalingual function, emotive function, referential function, poetic function and conative function expressed with code mixing used by the characters to show what is the meaning of the speaker in the sentence.
\end{abstract}

Keywords: code mixing, communicative function, Sold for Silver

\section{INTRODUCTION}

In sociolinguistics theory the study of mixing two languages together in one sentence called code mixing. As Wardaugh states, code mixing is a study about the mixing of two languages together in one sentence and can occur between speakers and single speaker.

In this research the researcher discusses one of the inspirational novels written by Janet Lim. The novel tells about the ability of the main character who can mix two languages, English and Malay, English and Chinese, along with English and Japanese in one sentence when she speaks. Moreover, this research also studies code mixing that occurs in the novel in expressing communicative function. The communicative function is divided into six types such as: Referential function, Emotive function, Conative function, Phatic function, Poetic function, and Metalingual function. 
The researcher is interested to invest more about code mixing to express the communicative function that happens when the characters mix two languages together, such as English to Malay, English to Chinese, and English to Japanese in the novel. In fact, code mixing also has become a worldwide phenomenon which is very important to study and analyze, because it helps the speaker to find the best word when the speaker faces limitation in vocabularies. This research focuses on what type of code mixing that use in the novel and how is the communicative function expressed by using code mixing.

\section{LITERATURE REVIEW}

\section{Sociolinguistics}

Sociolinguistic is one of the theories that study about the existence of language from the society. According to Trudgill, the study of sociolinguistics is related to cultural phenomenon. So the way people speak or talk will be determined by the social context (Trudgill, 2000). Society and linguistic are two aspects that cannot be separated.

Linguistics has social characteristics because of language is also social, language and culture are developed by certain society. Meanwhile, Chaika (1982, p.2) states that sociolinguistics is a study in which people use language in social interaction. Chaika also proposes the idea that language can maintain every social institution in human life.

People can use language for different purposes, it can be used to exchange the important information or just to greet someone. The use of language is influenced by the style of language and the way people speak. It is called language variation. Language variation includes code mixing and the function of language. One of the aspects of how society use code mixing and the function of language have been extensively studied through sociolinguistic and communicative function theory.

\section{Code Mixing}

In sociolinguistic there are many sub theories that explain about language, one of them is language variation. Language variation according to Hudson in Wardaugh "defines a variety of language as a set of sociolinguistic item with similar distribution that allows us to say that all of the following are varieties" (Hudson, 1996). The language varieties that the researcher will discuss on this research is code mixing that occurs in the conversation between the characters in Sold for Silver.

The theory that the researcher used to analyze the code mixing in Sold for Silver novel by Janet Lim is code mixing theory according to Wardaugh. According to Wardaugh:

People, then are usually required to select a particular code whenever they choose to speak, and they may also decide to switch from one code to another or to mix codes. Even within sometimes very short utterances and thereby create a new code in a process known as code switching. Code switching also called code mixing can occur in conversation between speaker's turn or within a single speaker's turn. In the later case, 
it can occur between sentence (inter-sententially) or within a single sentence (intra-sententially). Code switching can arise from individual choice or be used as a major identity marker for a group of speakers who must deal with more than one language in their common pursuits. (Wardaugh, 2006, p.101)

As Wardaugh mentions, the researcher considers code mixing, also called code switching, can occur between the speaker's turn or within a single speaker's turn. The researcher also divided the types of code mixing into two types such as intra-sententially and intersententially. The phenomenon of code mixing happens in bilingual or multilingual society. This phenomenon happens by the use of certain elements and a certain language.

Inter-sententially is code mixing or code switching that occurs between sentences when there is two speaker named A and B performs a dialogue and speaker A changes automatically into another language. It also occurs between speaker's turn. Meanwhile, intra-sententially occurs when there is only one speaker turn or within single sentence.

\section{Communicative Function}

Communicative function or mainly known as the function of language is introduced by the Russian-American linguist, Roman Jacobson. Communicative function can occur naturally based on the daily conversation, such as yelling, giving information about something, describing the statement, the slogans, or even greetings and casually discussing weather. Jacobson divides the communicative function into six, they are: referential function, emotive function, conative function, phatic function, metalingual function, and poetic function. Each of the function has the factors that caused the target factor, and operates the message of the target factor.

\section{The Referential Function}

Referential comes from the Latin word refero means something like "I bring back, I turn my self towards, I give notice". The referential function points at something "existing in the real world". It corresponds to the factor or context to describes a situation, object or mental state. The descriptive statement of referential function can consist of both definite descriptions and deictic words.

\section{The Emotive Function}

The emotive function has to do with what the text in and through itself reveals about the author or sender. It is also called expressive function. Jakobson states that it "is also called as expressive function that expressed (perhaps indirectly) about the sender and the sender's attitude towards what is being talked about or shown (1960, p.354)". It sometimes is followed by interjection and other sounds that changes into denotative meaning.

On the other hand, Jakobson (1987) also claims that the most common manifestation of the emotive function is the interjection. The speaker seeks to create the impression of certain emotion, either real or pretense. Simple expressions such as "oh!", "wow!" or "yeah!" are effective and authentic ways to express surprise, disgust, and anger without explicit statement or protracted description. For instance, the statement " there was a big snake in 
the kitchen!" might be simple referential, but if the speaker were to say " there was a biiiiiig snake in the kitchen!" It would more likely be intended and received as emotive because the prologue vowel is facts of the speaker's emotional reaction. To investigate the meaning of the language the reader must look at emotional and psychological connection between speaker and listener.

\section{The Conative Function}

The conative function has to do with the orientation towards the addresser that is influenced by the receiver. In verbal language the conative function can be seen in the imperative and vocative expression that are oftenmarked as having a separate grammatical form. It engages the addressee (receiver) directly and is best illustrated by vocatives and imperative. For example: "Miko! Come inside and eat!" or "open the door please!", etc.

\section{The Phatic Function}

The phatic function can be observed in greetings and casual discussion of the weather particularly with strangers. It also provides the keys to open, maintain, verify or close the communication channel.

\section{The Poetic Function}

The poetic function focuses on "the message for its own sake" (the code itself, and how it is used. According to Jacobson (1987: 7), poetic function is utterances that emphasize on sequences of word and the wider sense of the word deal with poetry. Poetic function focuses on aesthetic features of language and deals with that language whose primary focus is the beauty of the language itself.

6. The metalingual Function

The metalingual function concerns with utterances that deals with language or a linguistic nature. Furthermore, Jacobson (1987) states that metalingualistic functions to convey information about the lexical code of language, such as explaining the item with synonym, definition, paraphrase or examples

\section{Previous Related Research}

The first relevant research by Indira Kuniati in English Letters Department, Faculty of Adab and Humanity, State Islamic Unversity Syarif Hidayatullah Jakarta. It analyzescode mixing in the novel Nine Summer Ten Autumn by Iwan Setiawan. The theory used in this research is code mixing theory. The research aims to find a sociolinguistics analysis of code mixing. There are some differences and similarity, the difference is in the use of the different object. Meanwhile the similarity is the use of the same theory, which is sociolinguistic theory especially in code mixing theory. The result of Indira's research is the code mixing from English to Indonesia language that expressed interference.

The second relevant research is by Fitri Fuzi Astuti in Islamic Institute of Surakarta. It focuses on the code mixing found in Perahu Kertas by Dewi Lestari. There are some differences and similarity. The difference is the use of different object. The similarity is the 
use of code-mixing theory. The result of Fitri's research is the code mixing happens based on the form of word, phrase, clause, baster, reduplication/repetition of words and idioms.

The third relevant research is written by Yuliana, Lelly Suhartini, and Rohmana. It focuses on the analysis of speech function by English teachers at SMAN 5 Kendari. The difference lies on the object of the research. The similarity is the use of the same theory which is speech function or communicative function. The result of this research is the identification of communicative function expressed in the language.

\section{RESEARCH METHODOLOGY}

In analyzing Sold for Silver which uses several languages like Chinese, Japanese, and Malay, the researcher used descriptive qualitative method. Qualitative research relies on text and image, data, have unique method as in data analysis (Creswell: 2014). Qualitative research is useful in understanding and explaining how social phenomenon combined with linguistic phenomenon. This research also uses descriptive method because it involves data, analysis, and interpretation about how code mixing and communicative language is used. In this research the data that researcher find is reported by the words. Descriptive qualitative in this research is done by analyzing the type of code mixing and the communicative function during the interaction between the characters in Sold for Silver.

The procedure used by the researcher in the process of data collection is a contextual technique. This technique is used because it analyzes written documents. The steps include; first, the researcher read the theory of code mixing according to Wardaugh. Second, the researcher read the story behind Sold for Silver. Third the researcher repeatedly read to find the data related to code mixing. Fourth, after the researcher found the data by the conversation of the characters in the novel, the researcher classified the data into the table according to the type of code mixing that used in the novel. The researcher tried to comprehend the conversation related to the research question and analyzed it with code mixing theory according to Wardaugh. The researcher classified the data which contains the types of code mixing. Finally the researcher linked the data from code mixing into communicative function, and characterized each of the data based on each of communicative function. 
Prologue: Journal on Language and Literature Vol.7 No.2 (2021)

\section{FINDINGS AND DISCUSSION}

\section{Types of Code Mixing in Sold for Silver}

The types of code mixing found in the novel are intra-sententially and inter-sententially, The communicative function found in the novel is referential function, metalingual function, emotive function, conative function and poetic function. The findings of code mixing found are among English to Malay, English to Chinese and English to Japanese. The classification of amount data is presented in tables below. The most common data found is inter-sententially. Also, it is found that the most common code mixing happened is from English to Malay with the total amount 74 data

Table: 1 Code Mixing in Sold for Silver

\begin{tabular}{lcc}
\hline No. & Types of code mixing & Amount of data \\
\hline 1 & Intra-sententially & 61 \\
2 & Inter-sententially & 75 \\
\hline
\end{tabular}

Table: 2 Code Mixing based on languages in Sold for Silver

\begin{tabular}{lcc} 
& \multicolumn{2}{c}{ Table: 2 Code Mixing based on languages in Sold for Silver } \\
\hline No. & Languages & Amount of data \\
\hline 1 & English to Malay & 74 \\
2 & English to Chinese & 44 \\
3 & English to Japanese & 14 \\
4 & English to Malay and English to Chinese & 4 \\
5 & English to Malay and English to Japanese & 1 \\
\hline
\end{tabular}

\section{Communicative Function Expressed in Sold for Silver}

This part discusses about the communicative function expressed with code mixing. After the analysis process the researcher found several communicative functions. The total amount of data of communicative function is 86 data. Communicative function is found with the number of 47 data, making it the most found among the other function. It will be presented in the table below.

Table: 3 Communicative function in Sold for Silver

\begin{tabular}{lcccc}
\hline No. & Communicative function & Intra & Inter & Amount \\
\hline 1 & Metalingual function & 24 & 23 & 47 \\
2 & Poetic function & 1 & - & 1 \\
3 & Referential function & 15 & 13 & 28 \\
4 & Emotive function & 1 & 7 & 8 \\
5 & Conative function & 2 & - & 2 \\
\hline
\end{tabular}




\section{CONCLUSION}

After the process of analysis and interpretation of data, the researcher concludes that there are two types of code mixing used in Sold for Silver, they are intra-sententially and intersententially and the most code mixing happened in Sold for Silver is inter-sententially. There are 86 data of communicative function in Sold for Silver. The most common data found in the research are metalingual function, poetic function, emotive function, referential function, and conative function. The metalingual function is used by the characters to show the information and meaning contain in the sentence. The emotive function is used by the characters to show and express the emotion. Meanwhile, the poetic function is used by the characters to show the aesthetic word in language. The referential function is used by the character to reveal the deictic word contained in the sentence. The conative function is used to reveal the vocative expression or anger by the characters in the novel.

\section{References}

Ade, O. I. \& Oyeniyi. Okunoye, O. (2008) An Introduction Literature and Literary Criticism. National Open University of Nigeria.

Astuti, F. (2014) A study on Code Mixing found in Perahu Kertas Novel by Dewi Lestari. Unpublished thesis. Surakarta: State Islamic Institute of Surakarta.

Chaika, E. (1982) Language The Social Mirror. Massachusetts: Newbury House Publisher. Creswell, J. W. (2014) Research Design. USA: SAGE Publications.

Denzin, N. K. (1978) The research act: a theoretical introduction to sociolinguistics methods. New York: McGraw-Hill.

Hasan, A. \& Ammani, J. (2018) Function of Language. Unpublished thesis. Al-Qaddisiyah University.

Hebert, L. (2014) The Function of language. Retrieved 6 April 2019. From: http://www.cosignosemio.com/jakobson/functions-of-language.asp

Jakobson, R. (1960) Linguistics and poetic. Cambridge: Massachusetts Institute of Technology Press.

. (1985) Metalanguage as a Linguistic Problem. America: Kulontenyomat Nyevltudomany Kozlemenyek.

. (1987) Language in Literature. Cambridge: The Belknap Press of Harvard University Press.

Juel, H. (2013) A phenomenological approach to the analysis of media content.

Kothari, C. R. (2004) Research Methodology Methods and Techniques. New Delhi: New Age International Limited Publisher.

Kurniati, I. (2014) A sociolinguistics analysis of code mixing on Nine Summer Ten Autumn novel by Iwan Setiawan. Unpublished thesis. Jakarta: State Islamic University Syarif Hidayatullah.

Liem, J. (2004) Sold for Silver. Singapore: Monsoon Books.

Meriam, S. (2009) Qualitative research: A guide to design and Implementation. San Frasisco: Jossey Bass 
Prologue: Journal on Language and Literature Vol.7 No.2 (2021)

Omniglot. The online encyclopedia of writing system \& language, Useful Cantonese $\begin{array}{lllll}\text { Phrase. } & \text { Retrieved } & 12 & \text { July } & \end{array}$ https//www.omniglot.com/language/phrases/Cantonese.php

Sapir, E. (1921) Language introduction to the study of speech.

Sarongs History. The History of Sarongs. Retrieved 11 July 2019. From: $\mathrm{https//www.allsarongs.com/sarong-history-a/144.html} \mathrm{retrieved} 11$ July 2019 at 09:00 $\mathrm{pm}$

Sumardjo, Y. (1998) Apresiasi Kesusastraan. Jakarta : Gramedia.

Tribus, A. (2017) The Communicative Function of Language: An exploration of Roman Jakobson's theory in TESOL

Trudgil, P. (2000) Sociolinguistics: an introduction to language and society. England: Penguin Books.

Wardaugh, R. (2006) An Introduction of sociolinguistics. USA: Blackwell Publishing.

Yuliana, et.al. The Analysis of Speech Function used by English Teachers At SMAN 5 Kendari. Unpublished thesis. Halu Oleo University 